Article

\title{
Parliamentary Scrutiny of the European Semester: The Case of Poland
}

\author{
Christian Schweiger
}

Chair for Comparative European Governance Systems, Institute for Political Science, Chemnitz University of Technology, Germany; E-Mail: christian.schweiger@phil.tu-chemnitz.de

Submitted: 5 March 2021 | Accepted: 24 May 2021 | Published: 13 August 2021

\begin{abstract}
The European Semester became an essential part of the revised governance architecture of the Europe 2020 reform strategy for the Single European Market under the conditions of the global financial crisis and the emerging eurozone crisis a decade ago. The article examines to what extent the European Semester offers channels to establish throughput legitimacy by granting national parliaments the ability to effectively scrutinise executive decision-making in the annual policy cycle. Poland is chosen as the case study for parliamentary scrutiny of the EU's system of multi-level governance in the East-Central European region. The analysis adopts a liberal intergovernmentalist two-level approach. On the domestic level it concentrates on the involvement of the Sejm, the lower house of parliament, on the drafting of the Polish National Reform Plans for the annual Semester policy cycle between 2015 and 2020. The basis for the analysis are official transcripts from the plenary debates in the relevant committees, the European Affairs Committee and the Public Finance and the Economic Committee. The Polish case study illustrates that the European Semester represents a predominantly elitedriven process of policy coordination, which is strongly geared towards EU-level executive bargaining processes between national governments and the European Commission at the expense of domestic parliamentary scrutiny.
\end{abstract}

\section{Keywords}

economic governance; European Semester; European Union; national parliaments; Poland

\section{Issue}

This article is part of the issue "Rising to a Challenge? Ten Years of Parliamentary Accountability of the European Semester" edited by Eric Miklin (University of Salzburg, Austria), Aleksandra Maatsch (University of Wroclaw, Poland) and Tomasz P. Woźniakowski (Hertie School, Germany).

(C) 2021 by the author; licensee Cogitatio (Lisbon, Portugal). This article is licensed under a Creative Commons Attribution 4.0 International License (CC BY).

\section{Introduction}

This article concentrates on Poland as the case study for parliamentary input legitimacy in the East-Central European (ECE) region in relation to the EU-level European Semester annual coordinative policy cycle, which is integrated in the economic and social Europe 2020 reform strategy. The case study is determined not only by the fact that Poland the largest member state in the group of the ECE member states. The ECE countries not only have a less deep-seated tradition of parliamentary democracy than their Western neighbours. They also display tendencies towards backsliding from post-communist democratisation and moving towards semi-autocratic hybrid regimes or "velvet dictatorships" (Agh, 2019, p. 176) with weakening levels of parliamen- tary input and scrutiny, as well as independent judicial oversight. It is therefore crucial to particularly monitor to what extent parliaments in the countries in the region maintain input and scrutiny in the area of EU-level policymaking. Poland has also made an astonishing transformation from economic and social laggard towards economic leader in the region. At the time of accession to the EU in 2004, Poland was not only lagging behind in terms of its GDP per capita but with $19.1 \%$ of the population out of work, it also recorded the highest unemployment rate amongst the 2004 ECE- 8 accession group (Schweiger, $2014 a$, p. 178). Poland used the conditionality of EU membership to reform its labour market and improve its competitiveness, and ultimately decided to stay clear of joining the eurozone to maintain monetary policy as a means for economic policy-making. The combination 
of being closely tied to the German export production chain inside the Single European Market while remaining outside the eurozone and the prudent utilization of EU funds to target domestic vulnerabilities assisted Poland in acquiring the prime position of being the only country which stayed clear of recession during the global financial crisis and the subsequent eurozone sovereign debt crisis (Drozdowicz-Biec, 2011; Duszczyk, 2016, p. 253). The EU presents the European Semester as part of the implementation of the eurozone's reformed six pack governance rules in the context of a new complex system of multi-level governance. It is nevertheless obvious that the European Semester has shifted the balance substantially towards the European Commission in an attempt to strengthen its mandate as a supervisory and corrective agent, particularly in the eurozone. The European Parliament mainly plays a consultative role in the area of employment policy and is reduced to the role of a bystander in the European Semester coordination of national economic and budgetary policies. The European Semester hence displays a significant deficit in terms of legislative scrutiny on the EU level. In this respect it fits into the wider legitimacy problem of the EU. The EU is generally weak on ensuring the direct participation of citizens in its policy process. EU policies are mainly legitimised through national elections, where governments receive the mandate to negotiate EU-level treaties and policies on behalf of their citizens. This worked during the first three decades of the integration process, when the "permissive consensus" between citizens and government elites gave the latter the benefit of the doubt in producing efficient policy output (Chryssochoou, 2009, p. 30). It has however become increasingly constrained as the EU's institutional setting, its policy remit and the diversity of its membership grew over time. In the larger EU with its complex system of multi-level governance, where it has become ever more difficult for citizens to determine the responsibility for EU laws and policies, there is now the predominance of an obvious 'dissensus' under which public trust in political leadership has declined and scepticism towards national and EU level institutions, including national parliaments and the European parliament, has grown (Hooghe \& Marks, 2009 , p. 5). The latest Eurobarometer poll conducted in February-March 2021 shows very low levels of trust in national governments (35\%) and parliaments (36\%) and only slightly more in the EU and its institutions (49\%; European Commission, 2021b, p. 9).

National parliaments play a crucial role in ensuring the legitimacy of the EU policy process. They not only provide input legitimacy by acting as the main bodies, where the electoral choice of the sovereign is represented and where hence a government majority emerges which constitutes the basis for executive decision-making. They also play a crucial role in ensuring throughput legitimacy by monitoring and influencing legislative processes. The influence of national parliaments in the legislative process is consequently a crucial precondition to ensure efficient policy outcomes. Input legitimacy in the form of national elections therefore becomes the basis for ensuring transparent and efficient policy-making in the EU. Particularly the EU's complex system of multi-level governance requires transparency in order to be considered legitimate by the citizens in the member states against the background of growing public scepticism. Throughput legitimacy is therefore crucial "for evaluating the legitimacy of complex processes and procedures occurring within the 'black box' of multi-level governance, as it processes input demands through governance institutions to produce policy outputs" (Schmidt \& Wood, 2019, p. 729). The focus on the procedural quality of EU-level policy processes such as the European Semester in terms of both accountability and transparency is hence crucial to legitimise them on the domestic electoral constituency level. Comparative studies of the level of scrutiny of EU-level politics by national parliaments however display discouraging picture (Auel, 2007; Cornell \& Goldoni, 2017; Jancic, 2017). They have most of all emphasised that individual national parliaments lack the means to exercise direct input into the legislative process on the EU institutional level (BoronskaHryniewiecka, 2013, p. 91). Input into governmental decision-making on EU affairs on the domestic level is hence crucial.

In the Polish case the lower house of parliament, the Sejm, is the crucial piece in the legitimacy puzzle of the European Semester as monitoring of EU-level policy procedures such as the European Semester, takes place in the Sejm at committee stage. Legislative scrutiny of EU-level policy-making in a rather centralised system between the Polish government represented by the Council of Ministers and the Sejm takes mainly place in the European Affairs Committee, with additional involvement of the Public Finance and the Economic Committee in the case of policy areas which deal with single European market and eurozone issues, which is at the heart of the European Semester policy cycle. Previous analyses of the involvement of the Sejm committees in scrutinising EU level policies have pointed out that the level of parliamentary scrutiny in Poland is rather weak due to the non-binding nature of recommendations made by Sejm committees (Gärtner et al., 2011, p. 88).

The crucial research question which this article examines for the case of Poland is hence to what extent national parliaments are able to effectively scrutinise executive decision-making in the European Semester process. Effective scrutiny is here defined as a process where subsidiarity is continuously applied and parliamentary supervision of policy-making in the EU's multi-level governance system takes place as a process which ensures not only input legitimacy but most of all also throughput legitimacy. Following the definition by Schmidt and Wood this means that the analysis needs to concentrate both on the level of accountability and transparency of governance processes and also on their 
openness towards input from civil society (Schmidt \& Wood, 2019, p. 730).

The second section of the article sets out the methodological approach and theoretical framework which is based on a liberal intergovernmentalist two-level perspective and focused on throughput legitimacy. The third section briefly outlines the scope and the mechanisms of the European Semester in the context of the Europe 2020 Strategy. The main analysis of parliamentary scrutiny of the European Semester in the context of Poland's domestic polity is presented in the fourth section, followed by a concluding evaluation in the final section.

\section{Parliamentary Scrutiny of the European Semester: A Two-Level Approach towards Throughput Legitimacy}

\subsection{Theoretical Framework}

The analysis presented here follows the perspective of the two-level approach developed by Andrew Moravcsik's liberal intergovernmentalism, based on Putnam's original assumption that states play "two level games" between the interests of their domestic constituencies and external negotiations (Putnam, 1988, p. 434). This is significant as it is the basis for Moravcsik's liberal intergovernmentalist theory, which explains policy-making in the EU as a two-level game between the domestic political environment of each member state, secondly the supranational level of the Community, where interstate bargaining between member states and EU bodies takes place. On the domestic level, Moravcsik puts the emphasis on the need for national governments to develop their strategic policy preferences by taking into account the plurality of national interests. Governments hence consider electoral responses to their decisions but also take into account the representation of societal interests through public consultations with stakeholders. The extent to which the latter consultations take place inside legislative bodies or through other channels depends on the degree of institutionalised corporatism in each domestic polity. In polities with high levels of integrated policy coordination the level of interest group influence on executive policy decisions is higher than in those where the emphasis lies on the swift implementation of policy change. This can be seen by the practical operation of the varying degrees of corporatism found in the political economies of Nordic social democratic, continental conservative-corporatist and liberal models (Amable, 2003; Esping-Andersen, 1989). The degree of legislative involvement also depends on the extent to which governments consider it to beneficial to strengthen their standing in supranational bargaining processes through domestic parliamentary mandates.

Most importantly, Moravcsik's liberal intergovernmentalism considers national preferences to represent "the objectives of those domestic groups which influence the state apparatus" (Moravcsik, 1998, p. 24). It is hence crucial to determine to which extent the formation of national preferences takes place in a domestic policy cycle between public consultation, legislative scrutiny, and executive decision-making. This especially applies to the European Semester, which represents a to this date unprecedented experiment in multi-level policy coordination. The European Semester was relatively quickly established in response to the volatility caused by the global financial crisis and the subsequent triple banking, economic and sovereign debt crisis with the aim of instilling confidence and stability in the way governance works in the EU and particularly in the eurozone (Schweiger, 2016, p. 136).

The European Commission points out that the European Semester "allows EU countries to discuss their economic and budget plans and monitor progress at specific times throughout the year" (European Commission, 2021a). Liberal intergovernmentalism emphasises the fact that national governments benefit from being able to maintain the national preferences on the second level of bargaining with other member state governments and EU-level institutions, mostly in terms of their electoral standing (Moravcsik, 1993, pp. 483, 515). One would therefore assume that governments want to ensure that the national preferences they introduce on the supranational level of bargaining represent the plurality of domestic societal interests and that at the same time the bargaining process runs smoothly without major disruptions and delays. These assumptions point towards the need for national governments to effectively coordinate their policy agenda with domestic veto players to ensure that the national preferences reflect a relatively broad national policy consensus. It is obvious that governments in a parliamentary democracy have to consider both the formal institutional veto players (amongst them, national parliaments) who act as agents to prevent change and the partisan veto players (e.g., political parties) inside these institutions who can tilt the balance of political decisions (Tsebelis, 1995, p. 302). Especially concerning European policy-making however, governments are today confronted with growing Eurosceptic sentiments amongst the electorate who questions EU-level policies both in terms of democratic legitimacy and output efficiency. This results in what Schmidt describes as populist politics, which is directed both against policy issues (politics against policy) and the EU as a polity (politics against polity). The latter ultimately poses the risk of resulting in the gradual disintegration of the EU with Brexit being potentially the first step in a wider disintegrative tendency (Schmidt, 2020, p. 107).

\subsection{Methods and Data Analysed}

The two-level perspective adopted in this case study concentrates on the examination of the priorities determined in the Polish National Reform Plans in the European Semester policy cycle during the period from 2015 until 2020 and how these have been reflected in 
domestic parliamentary debates in the lower house of the Sejm at committee stage. For the latter purpose, transcript from the parliamentary committee meetings in the Sejm which deal with EU issues were considered. The analysis also considers internal parliamentary dynamics such as the influence of populist parties.

\section{The Europe 2020 Strategy and the European Semester}

For almost two decades now the European Union has been trying to implement an effective strategy against the persistent growth, employment, and competitiveness problem in many member states. The first attempt to coordinate national economic, employment and welfare policies was made in 2000, when the EU initiated the Lisbon Strategy with the target-based open method of coordination mechanism. The Lisbon Strategy was supposed to improve the performance of member states in the areas of growth and employment over the next decade by setting overall targets and encouraging national governments to engage in policy learning from the strategies implemented by the best performing member states. At the mid-term review in 2004 under the newly appointed Barroso Commission things looked bleak. The high-level group of experts under the leadership of Wim Kok, commissioned by Commission President Barroso to assess the performance of member states towards the Lisbon targets, essentially pointed out the lack of commitment and performance of many member states in the Lisbon process. The Kok report hence asked member states to step up their commitment towards the performance targets if they did not want to risk undermining "the sustainability of the society Europe has built" (European Commission, 2004, p. 16).

At the time of the Lisbon revision the Commission could certainly not anticipate the events that would unfold. They were of course completely unaware that during the next five years European economies would be hit by the effects of a sub-prime loan crisis in the financial industry in the United States. The resulting global financial crisis not only pushed back the performance of those countries that had already been amongst the worst performers in the EU; it also weakened particularly those liberal market economies with a strong dependence on the financial services industry, which before the crisis had been promoted as role models for competitiveness, stimulating growth and job creation (European Commission, 2004 , p. 10). The triple impact of an economic, banking, and sovereign debt crisis in many EU member states represented a fundamental setback to the ambition of the Lisbon Strategy to turn the Single European Market into the most dynamic and competitive economic area in the world.

The EU responded to this reality by developing a new and more sophisticated reform strategy, which was supposed to draw the lessons from the flaws of Lisbon. The Europe 2020 Strategy, initiated in March
2020, abandoned the narrow focus on growth and jobs and instead presented a wider set of targets which concentrate on generating competitiveness through innovation, making growth sustainable and achieving higher levels of social cohesion. The Commission proposed a more stringent set of targets which would be implemented on the basis of a new annual coordinative policy cycle (European Commission, 2010, p. 9). The resulting European Semester is described by the Commission as "a strong governance framework that harnesses the instruments at its disposal to ensure timely and effective implementation" (European Commission, 2010, p. 25) which enables the mutual discussion of national macroeconomic and budgetary reform plans. In terms of procedure the European Semester policy cycle is initiated by the discussion of the draft national budgets of the eurozone member states with the European Commission and by the publication of six analytical documents by the Commission:

1. The Annual Growth Survey, which determines the main challenges facing the EU collectively in terms of budgetary and macroeconomic development.

2. The Alert Mechanism Report focusing on existing and potential macroeconomic imbalances in the member states.

3. The Joint Employment Report, which summarizes the achievements and ongoing challenges for member states in this area.

4. The Euro Area Recommendation on specific reform proposals for the euro area made in cooperation with the Council.

5. The Single Market Report which is based on an economic forecast conducted by the European Commission four times a year (spring, summer, autumn, and winter).

6. The Opinions on the National Reform Plans (NRPs) issued by the member state governments.

In November each year national governments are required to submit national budgetary convergence and macroeconomic reform plans which are subsequently discussed in the Council on the basis of the draft country-specific recommendations issued by the European Commission. The final country-specific recommendations emerge on the basis of the interaction between the Commission guidelines and a collective adoption of the member states in the Council. Implementation of these recommendation subsequently depends on the domestic policy process. Monitoring by the Commission is more extensive if a country displays significant budgetary and/or macroeconomic imbalances and is particularly stringent for the countries of the euro area (European Parliament, 2020, p. 4).

In effect the European Semester consequently represents a process which predominantly focuses on intergovernmental bargaining between member state governments individually and collectively in the EU Council 
and with the European Commission. The European parliament plays a subordinate role in this process and according to its own assessment is mainly involved in the European Semester "through economic dialogue":

In the context of the dialogue, Parliament may invite the Presidents of the Council, the Commission, the European Council or the Eurogroup, to discuss documents and procedures relating to the European Semester. In addition, in the specific case where a Member State is subject to recommendations under the preventive and/or the corrective arm of the Stability Pact and the macroeconomic imbalance procedure, Parliament may invite a national representative from that Member State for an exchange of views. (European Parliament, 2019, p. 5)

The lack of European Parliament scrutiny of the process explains the need to focus on national parliaments as potential agents of establishing input, throughput, and ultimately also more effective output legitimacy. National parliaments are the natural focus of domestic constituents and hence offer the most promising strategy to "deepen the EU's procedural integrity in a way that will also strengthen its existential integrity" (Lacey \& Nicolaidis, 2020, p. 384).

\section{Poland Under the European Semester}

In 2015 Poland witnessed a profound change from the centre-right pro-European Civic Platform government under Prime Ministers Donald Tusk (2011-2014) and Ewa Kopacz (2014-2015) towards the right-wing populist and Eurosceptic Law and Justice (PiS) government of Andrzej Dunda. Under changing prime ministers, PiS has since cemented its leading role in Polish politics, always under the strong influence of Jaroslaw Kaczynski, who has been leader of PiS since 2003 and also served as Polish prime minister between 2006 and 2007. He is currently also deputy prime minister under Mateusz Morawiecki, who took over as prime minister from Beate Szydlo in 2017. PiS has shown a tendency to expand the powers of executive government at the expense of legislative and judicial powers. Against this background of democratic backsliding (Przybylski, 2018) it is important to examine to what extent individual areas of EU-level policy-making have been affected by the weakening of democratic mechanisms on the domestic level.

In the first available documents for Poland in the European Semester process in 2013 the main emphasis of the National Reform Programme was on rectifying the slump in economic growth to just above 1\%, continuing the downward trend in unemployment, which was just starting to fall again after it had slightly risen from 7\% in 2008 to just over $10 \%$ in 2013 . Moreover, the focus of Poland lay on reducing the significant percentage of people who were at the risk of poverty-25.8\% (Republic of Poland, 2013). The final Council recommendations on the Polish convergence programme highlighted the need for Poland to improve business conditions, particularly in the area of research and development and to ensure greater participation of young people and women in the labour market (European Council, 2013).

Poland has not received any notification of macroeconomic imbalances since 2013 (European Parliament, 2020 , p. 12). At the same time Poland's record of implementing the country specific recommendations issued by the European Commission and the Council is relatively poor. Between 2013 and 2018 Poland implemented on average only around $20 \%$ of the recommendations. It consequently remains at the bottom of the country-specific recommendation implementation score in the EU (Bénassy-Quéré \& Wolff, 2020, p. 17). In Poland, the governmental consultations with economic, scientific, and civil society stakeholders are framed by their involvement "in the process of updating the NRP and implementing the European Semester" (Republic of Poland, 2020, p. 87). Parliamentary involvement usually takes place in the form of a parliamentary hearing at Committee Stage in the lower house Sejm, which involves representatives from relevant ministries and also members of the European Parliament and subsequently a further hearing on the recommendations published by the Commission.

The European Semester cycle in Poland during the past five years has been characterised by a similar set of recommendation issued by the Commission and the Council, which essentially concentrated on the following areas:

- Fiscal consolidation and management.

- Pension reform (2015-2016 and again since 2019).

- Labour market reform to reduce segmentation, increase participation (especially of young people and women) and to adopt strategies to implement lifelong learning.

- Facilitate investment in infrastructure, especially energy, transport, and construction.

- Strengthen the innovation of the economy (since 2018) and countering the effects of the Covid pandemic (2020).

At the discussion with the EU Affairs, the Public Finance and the Economic Committee on the 2015 annual National Reform and Convergence Plans in the Sjem on 23 April 2015, the government emphasised that the number of recommendations put forward by the European Commission in their annual country report at the initial stage of the Semester cycle in February has declined and that they have also become less detailed. At the same time the government advised the parliamentary committees that legislative input is possible but will ultimately depend on the collective approval by the EU Council: "It is possible to change the wording of the recommendation without the approval of the Commission only if such a change is in favour of a majority of the members 
of the Council of the European Union" (Chancellery of the Sejm, 2015, p. 5). The discussions during the plenary hearing concentrated on the proposals of the European Commission to establish an independent Fiscal Council in Poland to propose and monitor measures to maintain the overall debt levels of Poland, which stood at just below $50 \%$ in 2014, within the $60 \%$ threshold of stability and growth pact (European Commission, 2015, p. 13). The background to this was Poland's ability to enter the eurozone, an issue which the Civic Platform administration of Prime Minister Donald Tusk (2007-2014) had emphasised as a crucial ambition for Poland to join the core of the European Union (Schweiger, 2014b, pp. 12-13). The members of Parliament (MPs) who took part in the public hearing expressed diverging opinions about the establishment of an independent Fiscal Council, which could eventually hold the powers to initiate widespread change to fiscal policies, such as pensions. Jerzy Żyżyński, MP for the Eurosceptic PiS, which subsequently won the 2015 national elections with the largest share of mandates, raised the general question why the European Commission proposed the establishment of an unelected body. He considered this proposal to be at risk of jeopardising the right of the Sejm to exercise its budgetary powers:

This is some artificial creation, the functioning of which is currently difficult to imagine. It is for the Sejm to pass the budget. Who would advise this? After all, the government formulates the draft budget, the Sejm debates on it later and it is the Sejm that actually passes the budget with some amendments. (Chancellery of the Sejm, 2015, p. 8)

In the 2015 update to the Semester Convergence Plan, submitted by the Polish government, the emphasis lay on maintaining the government commitment towards keeping the threshold of structural public debt in relation to the GDP to a maximum of $55 \%$ of public debt. The Fiscal Council is mentioned but the government expresses no intention to pursue this proposal further. Instead, government representatives point out that the Supreme Audit Office annually submits an assessment of the implementation of the national budget and on monetary policy to parliament, echoing the doubts of opposition MPs about the establishment of a separate independent body (Council of Ministers, 2015, pp. 9, 64).

Since the election of the second PiS administration in November 2016 the Annual Semester cycle has formally received the same level of parliamentary scrutiny as in previous rounds under the Civic Platform governments. Nevertheless, if one examines the extent of parliamentary scrutiny, it becomes obvious that the government is trying to push through its agenda without substantial input from MPs. This within the existing procedural rules under the 2011 Cooperation Act and mainly through the executive powers of the Sejm. Under the Cooperation Act, which determines relations between the Polish government and parliament, Sejm's European Union Affairs Committee (SUE), which consists of up to 46 members, has the duty to ensure that parliamentary oversight of developing and implementing EU law takes in relation to Poland takes place. The Council of Ministers therefore has the duty to make all related documentation available, including on "evaluations of annual legislative programmes of the European Commission drawn up by the European Parliament and by the Council"; usually these are submitted directly by the European Commission to the Sejm (Chancellery of the Sejm, 2021). The opinion of the EU Affairs Committee must be heard by representatives of the Council of Ministers in public parliamentary hearings on EU affairs and this should in practice be an integral part of the national preference formation which constitutes the first domestic level of the two-level game of EU policy-making according to the liberal intergovernmentalist perspective. The Council of Ministers is required to explain if it fails to take into account the opinion of the SUE in determining the official government position on the second level of supranational intergovernmental bargaining in the EU between member state governments with involvement of the Commission and other EU bodies (Chancellery of the Sejm, 2010, Articles 11-13). Closer examination of parliamentary hearing procedures reveals that since the 2016 parliament the powerful role of the speaker of the Sejm has been used by the right-wing Eurosceptic PiS administration to accelerate parliamentary hearings of government ministers by the SUE. As Maatsch shows in her analysis, the combination of speeding up legislative sessions, scheduling them at inconvenient times (such as late evenings), limiting the influence of stakeholders by decreasing the number of public hearings amount to "breaches of procedural correctness in the law-making process" which have become a common feature under the PiS government $(2021$, p. 17). During the parliamentary period 2014-2019, the number of total legislative sessions of the Sejm not only decreased from 102 to 86 when compared to the previous 2011-2015 parliamentary term; the most noticeable decrease is obvious in the number of occasions where MPs where able to hold the government to account by questioning ministers and given oral statements. The former decreased from 975 to 835 and the latter from 3552 to only 1806, which represents a significant deterioration in the level of parliamentary scrutiny. The PiS administration in Poland consequently pursues the 'rationalization' of policy-making through "attempts to strengthen or emancipate the position of the executive in law-making" by stretching existing parliamentary rules rather than to introduce institutional changes, which is one way right-wing populist parties expand executive powers at the expensive of the legislature, as is shown by studies in the Czech Republic (Zbiral, 2021, p. 6). In contrast, the case of Hungary shows a more direct disempowerment of parliament through constitutional changes which have limited the legislative and scrutiny powers of the Hungarian 
parliament towards the executive under the right-wing populist Fidesz majority government since 2012 (Ilonszki $\&$ Vajda, in press).

In the public hearing on the NRP in the Sejm on 13 April 2016 the government representative Jadwiga Emilewicz, Undersecretary of State in the Ministry of Development, emphasised the government's agreement with the assessment of the Polish situation presented by the European Commission in the country report published on 24 February 2016 (European Commission, 2016). At the same time, she pointed out the need for parliament to swiftly approve the reform plan: "The document will soon be submitted to the European Commission, therefore it is important that that today it will be widely accepted not only by the government but also by the parliament" (Chancellery of the Sejm, 2016, p. 4). During the hearing, a number of opposition MPs from the Civic Platform openly expressed their concern and discontent with the way answers they were trying to submit on the NRP were ignored by the government. MP Joanna Mucha voiced her dissatisfaction about the fact that the government representatives refused to answer questions from the MPs directly:

Madam President, it has never happened in our time that you would not be able to your ability to obtain information from the government. This is what the Sejm is for to perform a control function over government. As members, we have a duty, not only the right, to ask questions and receive answers. I am asking you to give me the floor, because you saw that I was reporting several times during the Minister's speech. (Chancellery of the Sejm, 2016, p. 12)

In the NRP published on 26 April 2016, the government emphasised that besides parliamentary scrutiny the process of preparing the report involved "a broad spectre of stakeholders from economic, scientific and civic society circles to participate in the work on drafting, implementation and monitoring of the NRP" (The Republic of Poland, 2016, p. 60). The consultation process is guided by an inter-ministerial team coordinated by the Economics Ministry. The emphasis in the Polish consultation process on the Annual Semester cycle since 2016 lies on this direct interaction between the government level and stakeholders, which includes regional authorities, employers' associations, trade unions, chambers of commerce and agriculture, NGOs, and research bodies. These consultation forums which run under the logo "Team for Europe" take place quarterly and therefore provide a constant input into the drafting of the NRPs and the monitoring of the implementation of the Annual Semester recommendations in Poland.

From the liberal intergovernmentalist perspective the PiS government has been pursuing a stakeholderorientated approach in the European Semester consultations at the expense of parliamentary scrutiny. As PiS has been governing the country on the basis of a major- ity in the Sejm since 2015 and also held the majority in the Senate until 2019, it could afford to neglect legislative scrutiny of the European Semester by the opposition parties. Instead, the focus has been on integrating stakeholders into the cycle through the "Team for Europe" approach. This confirms the observations made in studies on the domestic scrutiny of the European Semester process in other countries which have highlighted the fact that:

1. The acceptance or the contestation of reform proposals depends firstly on the economic agenda of governing and opposition parties.

2. Scrutiny of EU level policy guidance is more effective if pursued in plenary sessions rather than in committee hearings.

3. Governing parties prioritise their own domestic economic interests over effective scrutiny and compliance with external policy guidance. (Maatsch, 2017, p. 15)

The focus on other actors in the consultative process on the European Semester in Poland is hence not surprising, particularly given the low levels of institutionalisation of parties in East-Central Europe, shown in the lack of social embeddedness, high volatility, and problems with being considered as legitimate bodies to represent the public interest (Kriesi, 2014, p. 373). The limited parliamentary input in the European Semester process in Poland, particularly at the crucial stage of establishing the priorities of the national reform agenda, is not only reflected in the lower level of formal consultations than it is the case in the quarterly "Team Europe" consultations. It is also shown in the fact that the current PiS government has been clearly unwilling to adopt suggestions from opposition MPs. An example for this was the rejection to follow demands from opposition Civic Platform MPs to implement an independent Fiscal Council in Poland, which had been recommended by the European Commission and the Council. Although Poland currently remains the only EU member state without an independent Fiscal Council which oversees fiscal policy (European Parliament, 2019), at the hearing on 21 April 2017 the government representative Undersecretary of State in the Ministry of Finance Leszek Skiba firmly rejected the call of opposition MPs to follow the EU guidance in this respect:

Yes, there really is some belief that public finances could be more stable, if there was a Fiscal Council. This assumption seems unjustified. Actually, it is worth taking care of stable public finances, but this is not necessarily the right instrument for this purpose. (Chancellery of the Sejm, 2017, p. 4)

During parliamentary scrutiny of the NRP the following year the focus shifted towards criticism from government MPs towards the EU's alleged of focus on the national Polish priorities for economic reform, 
particularly in the social area. PiS MP Gabriela Maslowska asked the government to be cautious:

About simply making recommendations which treat the EU as if it pursues our own goals.... believe that we should be very careful and critical about these matters and prudence to make our economic and social development a priority for us. (Chancellery of the Sejm, 2018, pp. 12-13)

Aneta Piątkowska (Deputy Director of the Government Department of Innovation at the Ministry of Entrepreneurship and Technology) responded: "Another thing I want to point out, the recommendations-how can we translate-are yes really recommendations. It is still not a sure obligation to introduce and this is how it should be perceived" (Chancellery of the Sejm, 2018, p. 13). Under the PiS, government parliamentary scrutiny has hence shifted towards a more general criticism of the Annual Semester process itself, rather than on the development of a reform agenda in response to the annual Commission country report issued at the beginning of the year. The growing lack of commitment to the process was also echoed in the to this date final parliamentary hearing on a Polish Annual Semester NRPs in 2019.

The hearing on the Polish NRP 2019 in the Sejm on 11 April 2019 was dominated by a dispute between PiS and opposition MPs on the lack of accuracy and detail on the figures presented in the draft NRPs. The government, represented in this case by the Undersecretary of State in the Finance Ministry, Leszek Skiba, responded to these criticisms by admitting that it considered the purpose of the parliamentary hearing to not present the final recommendations of the NRPs but instead "general information about certain intentions, without prejudging the nature of the very details" (Chancellery of the Sejm, 2019, p. 15). The 2020 Annual Semester process in Poland took place without any parliamentary scrutiny. The government explains this as follows: "Due to extraordinary circumstances related to the COVID-19 crisis, neither the Sejm, nor the Senate could be involved in the discussions on the preparation of the National Reform Programme" (Republic of Poland, 2020, p. 87). The question remains if the government will use the crisis to attempt to shift the process further away from legislative scrutiny towards direct consultations with relevant stakeholders. It has certainly declared its intention to re-evaluate how the European Semester process is conducted in Poland. This review takes place exclusively on the executive level through the interministerial committee and with a strong focus on "improving the involvement of social partners in the process of the European Semester" (Republic of Poland, 2020, p. 87). In its recommendations for the Polish government under the 2020 European Semester policy cycle, the European Council did not specifically address the lack of legislative scrutiny in the determination of the Polish reform agenda. The Council nevertheless empha- sised that the Polish government should "ensure effective public consultations and involvement of social partners in the policy-making process," thereby highlighting that the process of determining Poland's European Semester NRP targets remains to focused on top-down decision-making by government executives (European Council, 2020, para. 30(4)).

\section{Conclusion: Evaluating the Polish Experience with the European Semester}

The analysis of the involvement of parliamentary input in Poland illustrates the general problem of the process, which is heavily tilted towards executive bargaining processes between national governments and the European Commission, both on an individual bilateral level and collectively in the Council. The Polish case shows that the danger that the process could result in "a formal and complex game whereby governments decide the policy, the EU formulates the country-specific recommendations and governments have to implement them" is indeed a realistic one (Alcidi \& Gros, 2017, p. 26). Although the Polish government includes a wide range of stakeholders through the "Team Europe" consultations, the level of parliamentary scrutiny remains weak. Formally it mainly takes place at committee stage. In terms of real input, the process lacks depth and more extensive mechanisms for individual MPs to get involved. Overall, this reflects the fundamental problem with the European Semester, which lies in the fact that from the two-level perspective the process is orientated towards bargaining on the second level, i.e., the supranational level between national governments and EU institutions, most of all the European Commission and the Council. The result has been that national governments shift their attention increasingly towards the supranational level, with less time and effort spent on domestic consultations and scrutiny (Crum, 2017, p. 274). At the same time national parliaments have shied away from disrupting the EU-level bargaining process with wide-ranging demands for scrutiny and policy changes (Fasone, 2014). Although the variety of parliamentary scrutiny of the different aspects of the European Semester varies considerably amongst EU member states-particularly between countries inside and outside of the eurozone (Hallerberg, 2017) - the Polish example not only exposes the fundamental problems of the process: constraining the ability of national governments to consider domestic legislatures and failing to compensate this on the EU level by also limiting the influence of the European Parliament to a purely consultative role. It also shows that particularly populist Eurosceptic governments tend to adapt existing parliamentary practices without necessarily amending them to limit legislative scrutiny in the context of the increasingly complex multi-level governance system of the EU. The Polish example consequently is in line with the general trend of the Europe 2020 Strategy which shows that it lacks efficient mechanisms to ensure 
parliamentary input and throughput legitimacy, both on the supranational European Parliament level as on the crucial domestic level of parliamentary scrutiny. While this may not necessarily result in a lack of efficient policy output in the process of aspiring to achieve the overall Europe 2020 targets, the lack of parliamentary input and throughput scrutiny mechanisms pose a substantial risk for the level of public ownership of the European Semester policy process. This needs to be considered under the successor strategy of Europe 2020, which is most likely to lead towards the revision of existing policy practices, which will have the task of "ensuring a more citizen-driven and more decentralised democratic system while using the advantages of fair economic cooperation at a global level" (King, 2017, Slide No. 13).

\section{Conflict of Interests}

The author declares no conflict of interests.

\section{References}

Agh, A. (2019). Declining democracy in East-Central Europe: The divide. Edward Elgar.

Alcidi, C., \& Gros, D. (2017). How to further strengthen the European semester? European Parliament.

Amable, B. (2003). The diversity of modern capitalism. Oxford University Press.

Auel, K. (2007). Democratic accountability and national parliaments-Redefining the impact of parliamentary scrutiny. European Law Journal, 13, 487-504.

Bénassy-Quéré, A., \& Wolff, G. (2020). How has the macro-economic imbalances procedure worked in practice to improve the resilience of the euro area? European Parliament Committee on Economic and Monetary Affairs. https://www.bruegel.org/wpcontent/uploads/2020/03/IPOL_STU2020645710_ EN.pdf

Boronska-Hryniewiecka, K. (2013). Legitimacy through subsidiarity? The parliamentary control of EU policymaking. Polish Political Science Review, 1(1), 84-99.

Chancellery of the Sejm. (2010). Act on the cooperation of the council of ministers with the Sejm and Senate in matters relating to the Republic of Poland's membership of the European Union.

Chancellery of the Sejm. (2015). Full record of the course of the meeting of the European Union Affairs Committee (No. 337), Public Finance Committee (No. 468), Economic Committee (No. 155).

Chancellery of the Sejm. (2016). Full record of the course of the meeting of the European Union Affairs Committee (No. 47), Public Finance Committee (No. 48), Committee on Economy and Development (No. 23).

Chancellery of the Sejm. (2017). Full record of the course of the meeting of the European Union Affairs Committee (No. 127), Public Finance Committee (No. 198), Committee on Economy and Development (No. 73).

Chancellery of the Sejm. (2018). Full record of the course of the meeting of the European Union Affairs Committee (No. 196), Public Finance Committee (No. 316), Committee on Economy and Development (No. 105).

Chancellery of the Sejm. (2019). Full record of the course of the meeting of the European Union Affairs Committee (No. 260), Public Finance Committee (No. 434), Committee on Economy and Development (No. 149).

Chancellery of the Sejm. (2021). The Sejm and the European Union. European Information and Documentation Center-Sejm. http://www.oide.sejm.gov.pl/ oide/en/index.php?option=com_content\&view= article\&id=14283:the-sejm-and-the-europeanunion \& catid $=4 \&$ Itemid $=814$

Chryssochoou, D. N. (2009). Theorizing European integration (2nd ed.). Routledge.

Cornell, A. J., \& Goldoni, M. (Eds.). (2017). National and regional parliaments in the EU-legislative procedure post Lisbon. Hart Publishing.

Council of Ministers. (2015). Multiannual financial country plan for the years 2015-2018.

Crum, B. (2017). Parliamentary accountability in multilevel governance: What role for parliaments in postcrisis EU economic governance? Journal of European Public Policy, 25(2), 268-286.

Drozdowicz-Biec, M. (2011). Reasons why Poland avoided the 2007-2009 recession. Prace i Materiały, 86(2), 39-66. https://ideas.repec.org/a/wsd/irgpim/ v86y2011i2p39-66.html\#download

Duszczyk, M. (2016). Periphery, or perhaps already the centre? The impact of ten years of membership in the European Union on the position and perceptions of Poland. In J. M. Magone, B. Laffan, \& C. Schweiger (Eds.), Core-periphery relations in the European Union: Power and conflict in a dualist political economy (pp. 251-266). Routledge.

Esping-Andersen, G. (1989). The three worlds of welfare state capitalism. Polity.

European Commission. (2004). Facing the challenge: The Lisbon strategy for growth and employment (Report from the high-level group chaired by Wim Kok). https://ec.europa.eu/research/evaluations/pdf/ archive/fp6-evidence-base/evaluation_studies_ and_reports/evaluation_studies_and_reports_ 2004/the_lisbon_strategy_for_growth_and employment_report_from_the_high_level_ group.pdf

European Commission. (2010). Communication from the commission: Europe 2020-A strategy for smart, sustainable and inclusive growth. https://ec. europa.eu/eu2020/pdf/COMPLET\%20EN\%20 BARROSO\%20\%20\%20007\%20-\%20Europe\%202020 \%20-\%20EN\%20version.pdf

European Commission. (2015). Country report Poland 2015. https://ec.europa.eu/info/sites/info/files/ file_import/cr2015_poland_en_0.pdf

European Commission. (2016). Country report Poland 2016.

European Commission. (2021a). The European semester. 
https://ec.europa.eu/info/business-economyeuro/economic-and-fiscal-policy-coordination/ eu-economic-governance-monitoring-preventioncorrection/european-semester_en

European Commission. (2021b). Standard Eurobarometer 94: Winter 2020-2021. https://europa.eu/ eurobarometer/surveys/detail/2355

European Council. (2013). Council recommendation of 9 July 2013 on the national reform programme 2013 of Poland and delivering a council opinion on the convergence programme of Poland, 2012-2016. https://eur-lex.europa.eu/legal-content/EN/TXT/ ?uri=CELEX:32013H0730(16)

European Council. (2020). Recommendation for a council recommendation on the 2020 national reform programme of Poland and delivering a council opinion on the 2020 convergence programme of Poland (COM/2020/521 final). https://eur-lex.europa.eu/ legal-content/EN/TXT/?qid=1591720698631\&uri= CELEX:52020DC0521

European Parliament. (2019). The role of national fiscal bodies. State of play: April 2019. https://www. europarl.europa.eu/RegData/etudes/IDAN/2019/ 634386/IPOL_IDA(2019)634386_EN.pdf

European Parliament. (2020). Background reader on the European semester: The European semester from a parliamentary perspective. https://www.europarl. europa.eu/RegData/etudes/STUD/2020/624444/ IPOL_STU(2020)624444_EN.pdf

Fasone, C. (2014). European economic governance and parliamentary representation. What place for the European parliament? European Law Journal, 20(2), 164-185.

Gärtner, L., Hörner, J., \& Obholzer, L. (2011). National coordination of EU policy: A comparative study of the twelve "new" member states. Journal of Contemporary European Research, 7(1), 77-100.

Hallerberg, M. (2017). Explaining the evolving role of national parliaments under the European semester. Journal of European Public Policy, 25(2), 250-267.

Hooghe, L., \& Marks, G. (2009). A postfunctionalist theory of European integration: From permissive consensus to constraining dissensus. British Journal of Political Science, 39(1), 1-23. https://ec.europa.eu/ info/sites/info/files/cr_poland_2016_en.pdf

Ilonszki, G., \& Vajda, A. (in press). How far can populist governments go? The impact of the populist government on the Hungarian Parliament. Parliamentary Affairs.

Jancic, D. (2017). National parliaments after the Lisbon Treaty and the Euro crisis. Oxford University Press.

King, B. (2017). Why do we need a successor to the EU2020 strategy? [PowerPoint presentation]. https://www.eesc.europa.eu/en/news-media/ presentations/why-do-we-need-successor-eu2020strategy

Kriesi, H. (2014). The populist challenge. West European Politics, 37(2), 361-378.
Lacey, J., \& Nicolaidis, K. (2020). Democracy and disintegration: Does the state of democracy in the EU put the integrity of the union at risk? In R. Coman, A. Crespy, \& V. A. Schmidt (Eds.), Governance and politics in the post-crisis European Union (pp. 378-397). Cambridge University Press.

Maatsch, A. (2017). Effectiveness of the European semester: Explaining domestic consent and contestation. Parliamentary Affairs, 70(4), 691-709.

Maatsch, A. (2021). Disempowerment through the backdoor: The impact of populist parties on the national parliament in Poland. Parliamentary Affairs, Article gsab008.

Moravcsik, A. (1993). Preferences and power in the European community: A liberal intergovernmentalist approach. Journal of Common Market Studies, 31(4), 473-519.

Moravcsik, A. (1998). The choice for Europe: Social purpose and state power from Messina to Maastricht. UCL Press.

Przybylski, W. (2018). Explaining Eastern Europe: Can Poland's backsliding be stopped? Journal of Democracy, 29(3), 52-64.

Putnam, R. D. (1988). Diplomacy and domestic politics: The logic of two-level games. International Organizations, 42(3), 427-460.

Republic of Poland. (2013). National reform programme Europe 2020: 2013/2014 update. European Commission. https://ec.europa.eu/info/sites/info/files/file_ import/nrp2013_poland_en_0.pdf

Republic of Poland. (2016). National reform programme Europe 2020: 2016/2017 update. European Commission. https://ec.europa.eu/info/sites/info/files/ european-semester-national-plan_poland_2016_ en.pdf

Republic of Poland. (2020). National reform programme Europe 2020. European Commission. https://ec. europa.eu/info/sites/info/files/2020-europeansemester-national-reform-programmepoland_en.pdf

Schmidt, V. A. (2020). Rethinking EU governance: From 'old' to 'new' approaches to who steers integration. In R. Coman, A. Crespy, \& V. A. Schmidt (Eds.), Governance and politics in the post-crisis European Union (pp. 94-114). Cambridge University Press.

Schmidt, V. A., \& Wood, M. (2019). Conceptualizing throughput legitimacy: Procedural mechanisms of accountability, transparency, inclusiveness and openness in EU governance. Public Administration, 97, 727-740.

Schweiger, C. (2014a). The EU and the global financial crisis: New varieties of capitalism. Edward Elgar.

Schweiger, C. (2014b). Poland, variable geometry and the enlarged European Union. Europe-Asia Studies, 66(3), 394-420. https://doi.org/10.1080/09668136. 2013.869898

Schweiger, C. (2016). Exploring the EU's legitimacy crisis: The dark heart of Europe. Edward Elgar. 
Tsebelis, G. (1995). Decision making in political systems: Veto players in presidentialism, parliamentarism, multicameralism and multipartyism. British Journal of Political Science, 25, 289-325.
Zbiral, R. (2021). Do coalition governments with populist parties attempt to rationalise law-making in parliaments? Evidence from the Czech chamber of deputies. Parliamentary Affairs, Article gsab011.

\section{About the Author}

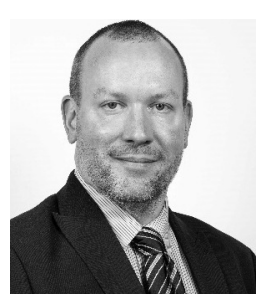

Christian Schweiger (PD Dr.) is Visiting Professor at the Chair for Comparative European Governance Systems in the Institute for Political Science at Chemnitz University of Technology, Germany. His research concentrates on comparative politics and comparative political economy in the European Union, transition politics, and transatlantic relations. His most recent publications include the article "Deutschland einig Vaterland? East-West Cleavages in Germany Thirty Years after Reunification" (German Politics and Society, 2020) and "Perspectives for German-Polish Relations in the EU-27" (Review of European Affairs, 2020). 